\title{
Investigation of Perceived Organizational Identification from Different Generations: TRC1 (Gaziantep, Adiyaman, Kilis) Zone Example of Organized Industrial Enterprises*
}

\author{
Gulsen Kirpik ${ }^{1}$ Bunyamin Akdemir ${ }^{2}$ \\ 1.Pharmacy Faculty, Department of Pharmacy Management, Adiyaman University, PO Box 02240, Adiyaman, \\ Turkey \\ 2.Faculty of Economics and Administrative Sciences, Inonu University, PO Box 44280, Malatya, Turkey
}

\begin{abstract}
The rapid changes and developments in the environment of enterprises have led to changes in the perceptions of employees from different generations as well as the activities of the enterprises. In particular, the organizational identification levels of the different generation of employees in organized industrial enterprises, which play an active role in the regional economic development of the countries, have become one of the key factors in achieving the goals and objectives of the enterprises in order to carry out their activities continuously. Because, organizational identification differences of different generations also affect employees' expectations, perceptions, attitudes and behaviors towards the organization. It has become inevitable for the enterprises that have to be successful in reaching their goals and targets thanks to the employees of different generations, giving the necessary importance to the organizational identification that creates positive business results. In this study, perceived organizational identification level is examined in terms of different generations. In this context, the data set of the study was reached with the survey method applied to 1,105 employees selected by random sampling method among the employees in the organized industrial enterprises of TRC1 Zone. SPSS 22.0 program was used to analyze the data set. Within the scope of data analysis, frequency analysis, reliability analysis, normal distribution test and factor analysis were applied.The reliability coefficient of the organizational identification scale used in the study was 0.927 . The level of consistency between factor analysis and items of organizational identification scale was found to be excellent and significant $(\mathrm{KMO}=0.948$; Barlett's Test Sig. $=0.000)$. In addition, with the Rotated Factor Matrix, the organizational identification scale has reached a two-dimensional structure. The first di mension of the scale was named as cognitive identification and the second dimension was called emotional identification. In addition, as a result of the normality test, it was found that the data did not show a normal distribution characteristic $(\mathrm{p}<0.01)$. Spearman rho correlation test was used to determine whether there is a significant relationship between the cognitive and emotional identification dimensions of the organizational identification scale. According to the results of the study, significant differences were found between the cognitive and emotional dimensions of organizational identification of the different generation employees $(p=0.00$ and 0.00 $<0.05$ ). In addition, a significant positive and significant relationship was found between cognitive and emotional identification dimensions of the organizational identification scale. According to the results of the study, suggestions were made for future researches.
\end{abstract}

Keywords: Organizational identification, Generation X, Generation Y, Generation Z, TRC1 Zone.

DOI: $10.7176 / \mathrm{JEP} / 10-22-09$

Publication date: August $31^{\text {st }} 2019$

\section{Introduction}

It is known that different generation members work together in today's business life. Different generations of people working for different expectations and purposes, differences in the way they do business, make it difficult for organizations to achieve successful results due to these differences. In this respect, it is important to reveal the similarities and differences of different generation employees in organizations.

The success of different generations working together for various reasons in the Organized Industrial Zones (OIZ), which has a very important place in the economy of our country, is important for the continuity of these enterprises. In addition to this, increasing the levels of perceived organizational identification by managing different generations together effectively and professionally, and ensuring their continuity in enterprises is one of the issues that need to be addressed for managers and employers. Which generation wants to be managed and how? How can the generations be motivated? What should be the hierarchy in the organization? etc. answering these questions will increase the level of identification between employees and the organization.

In this context, the aim of this study is to examine the levels and differences of organizational identification perceived by different generation employees in organized industrial enterprises of TRC1 Zone. The aim of this study is to contribute to the literature by providing information about the researches in the field and to show that intergenerational cooperation and collaboration is a critical element for the success of enterprises in a rapidly changing environment. 


\section{Literature Summary}

1.1 Organizational Identification

When the literature is examined, it is seen that some of the studies related to organizations are aimed at examining the definitions made by employees in relation to their organizations. The concept of identification used to explain the link between the organization and the employee expresses the commitment of the employee to the organization (Duttun, Dukerich and Harquail, 1994: 239). When we look at the dictionary meaning of the word identification, it is defined as the process of an individual's participation in their lives and emotions to the extent that they realize personality fusion with other individuals. (www.tdk.gov.tr, Access: 25.11.2018). In the table below, some definitions in the literature about organizational identification are given.

Table 1. Definitions of organizational identification

\begin{tabular}{|c|c|}
\hline Author & Definitions of Organizational Identification \\
\hline Simon (1947: 218) & $\begin{array}{l}\text { It is the process of fulfilling one's own goals, such as organizational goals, value indexes } \\
\text { that determine their own organizational decisions. }\end{array}$ \\
\hline Foote (1951) & It is the allocation and loyalty of a particular identity. \\
\hline $\begin{array}{l}\text { Kellman (1961: } \\
493)\end{array}$ & It is commitment on the basis of the desire for relationship. \\
\hline $\begin{array}{l}\text { Hall et al. (1970: } \\
\text { 176) }\end{array}$ & $\begin{array}{l}\text { It is the process in which the goals of the organization and the individual become } \\
\text { increasingly integrated and harmonious. }\end{array}$ \\
\hline Patchen (1970) & It is defined as shared qualities, loyalty and solidarity. \\
\hline Lee (1971) & It is the degree of individual identification with the organization \\
\hline Cheney (1983: 342) & $\begin{array}{l}\text { It is an active process in which the individual attaches himself / herself to the elements } \\
\text { on the social scale. }\end{array}$ \\
\hline $\begin{array}{l}\text { Ashforth and Mael } \\
(1989: 21)\end{array}$ & $\begin{array}{l}\text { It is related to the perception of unity against an organization and the perception of } \\
\text { belonging or unity towards the group, including success and failure situations. }\end{array}$ \\
\hline $\begin{array}{l}\text { Bullis and Bach } \\
(1991: 181)\end{array}$ & $\begin{array}{l}\text { It is the process of development of the relationship between the individual and the } \\
\text { organization, and is also the product of this process. }\end{array}$ \\
\hline $\begin{array}{l}\text { Efraty et al. (1991: } \\
64)\end{array}$ & It is the conformity between the identities of the individual and the organization. \\
\hline Pratt (1998: 172) & $\begin{array}{l}\text { is when an individual's beliefs about her organization are his / he } \\
\text { self-identifier. }\end{array}$ \\
\hline
\end{tabular}

Source: Saruhan, Sümeyra (2017). The Effect of Organizational Socialization on Organizational Identification. (Unpublished Master's Thesis) Kırlkkale University, Institute of Social Sciences, Kırlkkale, page 32.

In the process of identification, individuals accept the characteristics they perceive about the group as their own and form a new self. This newly formed self makes the other features of the individual become insignificant. Identification also occurs after this stage (Mael and Ashfort, 1989: 26). Depending on the degree of identification, the self formed by the employees with their organizations becomes central and when the employees express themselves, their organizational identities become more prominent than their other identities (Cirakoglu, 2010: 2). In other words, if the expressions used to define themselves are the same as the expressions they use to define the organization they are working for, then they identify themselves with the organization. Hence, organizational identification is a cognitive / perceptual concept and in order for organizational identification to occur, a psychological connection must be established between the individual and the fate of the organization (Mael and Ashfort, 1992: 105). In order for organizational identification to occur, the individual must perceive the corporate identity as striking and classify the self with the organization (Pratt, 1998: 194). In other words, the more similar the expressions that individuals use to identify themselves and the expressions they use to identify their organizations, the higher the identification with the organization (Dutton et al.,1994: 239). In other words, organizational identification is the perception of employees that they establish with one another and that they are similar (Polat and Meydan, 2010: 145; Dutton et al., 1994: 239).

Employees identified with their organizations will voluntarily engage in supportive behaviors of their organizations and will make more voluntary efforts to benefit the organization. Employees' identification with the organization makes their work more meaningful to them and thus motivates them more. The results of identification do not only increase economic efficiency. It also makes individuals feel emotionally happy (Cakinberk et al., 2011: 91).

The employee's level of organizational identification indicates the degree of commitment of the individual to his or her organization. If the employee has adopted membership in the organization and made it more important than other social group memberships, then this person is highly identified with the organization (Karabey and Iscan, 2007: 232). Employees' identification with the organization makes their work meaningful and increases motivation. However, it reduces the likelihood of alienation by increasing the desire to remain in the organization. Employees identified with their organizations will turn to supportive behaviors and make voluntary efforts for the 
benefit of the organization (Iscan, 2006: 161).

\subsection{Generation Concept and Classification of Generation}

Auguste Comte, who made the first scientific researches on the concept of generation, showed that intergenerational changes are the forces acting in the historical process and that social progress can only be achieved through the accumulation of one generation to the next generation (Toruntay and Dereli, 2011: 64).

In general, when the literature is examined, a generation is a group of individuals who share common experiences and attitudes over a period of time, and the members of this group are born in a common time frame; coexist with historical events occurring during this time period; and to experience the social changes in the process together; and so on they have common behavioral tendencies and feelings (Stern, 2002: 187; Erden, 2012: 5). Each generation has certain characteristics and value judgments. Therefore, individuals exhibit characteristics similar to the behaviors of the generation they were born in, while they exhibit characteristics different from those of other generations. For example, someone born in 1954 is affected by the events of the 1960s in his childhood and in the 1970s during his young adulthood. Therefore, as a result of the experiences gained during these periods, one has developed different values from his family by developing his own value judgments and attitudes (Karaaslan, 2014: 31). However, researches on generations show that generations return to the beginning every 100 years (Ertas, 2017: 3).

Generation classification is as follows (Adiguzel, Batur ve Eksili, 2014: 169-170);

- Traditionalists (1922-1945)

- Baby boomers (1946-1964)

- Generation X (1965-1978)

- Generation Y (1978-2000)

- Generation Z (2000-... )

The studies carried out in our country are mostly in the form of youth research and the generations are tried to be grouped by taking into account the political history of the country. However, there is no systematic generation survey that deals with generations in a sociological, biological and psychological framework. As stated by Karaaslan (2014: 36), since the United States is the country where the generations are mostly studied, this study is based on the United States-based classification.

\subsection{Other Related Studies}

In the study conducted by Ertas (2017) a total of 98 people were investigated by using the Likert scale with quantitative method and the expectations of the generations from the organization and each other. As a result of the research, it is stated that the $\mathrm{X}$ and $\mathrm{Y}$ generations have different dynamics, and that the management approach that provides more choice and movement space should be shifted out of the traditional business patterns.

In the study conducted by Aka (2017), strong and meaningful findings were obtained regarding the perspectives of generational differences of managers working in public and private sector organizations and organizational commitment levels. The generation with the highest level of organizational commitment was determined to be the Baby Boomers generation. According to this study, the level of organizational commitment was found to decrease as the generation members became younger.

In the study conducted by Usta (2014), the content of the questionnaire applied to the participants consists of demographic characteristics and whether the participants are aware of generation conflict in business life. When the data obtained as a result of the study is examined, it is observed that there are differences between the generations in the dimensions of business, management, prestige, lifestyle and diversity (change). When the above studies are evaluated together; While there are researches about generation differences, organizational commitment and other business values, it is seen that organizational identification and generation differences are not studied in the literature. This points out that the research topic has an important place in the literature and will be useful to academicians, researchers and students for future research.

\section{Research}

The aim and limits of the research, population and sample, data collection and analysis, research hypotheses, reliability analysis, factor analysis and method of analysis of hypotheses are included under this title.

\subsection{Purpose of the research}

The aim of this study is to examine the perceived level of organizational identification in terms of different generations. In addition, the results of the study are intended to provide guidance to various levels of stakeholders (human resources experts, managers, researchers, etc.) and to support the accumulation of knowledge in the academic literature.

This study is limited to the TRC1 Zone only. In the study, a relatively small sample of Turkey's Organized Industrial Zone were discussed. The findings may not be generalized to other employees of national or international 
scope. Because, the factors that affect the perception of organizational identification of generations may differ in regional or cultural terms. In addition, it may be different to correctly understand and answer each of the questions that constitute the organizational identification scale used as a data collection tool. However, it was accepted that the participants understood the questionnaire questions correctly and in the same way and gave answers and information reflecting the real situation.

\subsection{Population and Sample}

The main population of this study is the employees in the enterprises operating in the Organized Industrial Zones of TRC1 Zone (Gaziantep, Adiyaman, Kilis). Gaziantep Organized Industrial Zone is divided into 4 active industrial zones and 120.000 employees are employed in total (www.gaosb.org. 01.01.2015). When the information of Adiyaman Governorate in 2016 (www.adiyaman.gov.tr. 28.10.2017) is examined, it is seen that the current employment in Adiyaman Organized Industrial Zone is approximately 10.888 people. Furthermore, when the information of the official website of the Directorate of Kilis Organized Industrial Zone in 2015 (www.kilisosb.org.tr. 13.07.2015) is examined, it is seen that the current employment in Kilis Organized Industrial Zone is approximately 781 people. Taken together, the main population of this study is 131,669 in TRC1 Region. In this study, the sample consisted of 1,105 employees selected by random random sampling method. Accordingly, $0.8 \%$ of the TRC1 population has been reached.

\subsection{Data Collection and Analysis}

In order to collect data from the first hand, the questionnaire was prepared in the form of multiple choice to identify the employees and the questions that should be answered according to the five-point Likert-type scale. The questionnaires were applied by face to face interviews with 1105 employees who participated in the survey in the industrial zones of Gaziantep, Adiyaman and Kilis in April, May, June and July 2017 by simple random sampling method.

In this study, it was decided to use the organizational identification scale developed by Cheney (1982) in order to determine the organizational identification levels of the employees. The first version of the scale had 30 items and was reduced to 25 questions (Cakinberk et al., 2011: 99; Balci et al., 2012: 55). As a result of the researches and investigations, the 18-item scale used by Cakinberk et al. (2011) and Balci et al. (2012) was used for organizational identification.

The questionnaire used in the research consists of two parts. In the first part of the questionnaire, there are questions that determine the demographic characteristics of the participants. In the second part of the questionnaire, it was prepared with a 5-point Likert Type Scale and the questionnaire was given to the participants and they were asked to answer these questions. The data set was formed by coding the questions in the questionnaire form. SPSS 22.0 software was used to analyze the data set.

Before the analysis of the data, the Kolmogrov-Smirnov test was used to determine whether the data in the study showed normal distribution. As a result of Kolmogrov-Smirnov Test applied to the data, it was found that the data did not show normal distribution $(\mathrm{p} \leq 0.01)$. Since the data were not normally distributed, Kruskal Wallis $\mathrm{H}$ test, which is one of the nonparametric tests, was applied to the hypothesis tests. In our study, $5 \%$ error margin is predicted within $95 \%$ reliability limits.

\subsection{Research Hypotheses}

The main hypothesis for the purpose of the study and the sub-hypotheses formed in terms of two dimensions of organizational identification are given below.

1. $\mathrm{H}_{0}$ : There are no significant differences between the levels of organizational identification perceived by different generation employees.

1. $\mathrm{H}_{1}$ : There are significant differences between the levels of organizational identification perceived by different generation employees.

Sub-Hypotheses

$\mathrm{H}_{0.1 .1}$ : There are no significant differences between the perception levels of different generation employees regarding the cognitive dimension of organizational identification.

$\mathrm{H}_{1}$.1.1: There are significant differences between the perception levels of different generation employees regarding the cognitive dimension of organizational identification.

$\mathrm{H}_{0}$.1.2: There is no significant difference between the perception levels of the different generation employees regarding the affective dimension of organizational identification.

$\mathrm{H}_{1}$.1.2: There is significant difference between the perception levels of the different generation employees regarding the affective dimension of organizational identification.

2. $\mathrm{H}_{0}$ : There was no significant relationship between cognitive and affective dimensions of perceived organizational identification.

2. $\mathrm{H}_{1}$ : There was significant relationship between cognitive and affective dimensions of perceived organizational 
identification

2.5 Research Reliability and Factor Analysis

In this part of the study, factor analysis, reliability analysis and results are given. The results of factor analysis, Kaiser Meyer-Olkin (KMO) test and Barlett Sphericity Test results are given in Table 2 below.

Table 2. Reliability and Factor Analysis

\begin{tabular}{lcccc}
\hline \multicolumn{1}{c}{ Survey Question Groups } & $\begin{array}{c}\text { Number of } \\
\text { questions }\end{array}$ & $\begin{array}{c}\text { Kaiser Meyer- } \\
\text { Olkin }\end{array}$ & $\begin{array}{c}\text { Bartlett Sphericity } \\
\text { Test Sig. }\end{array}$ & $\begin{array}{c}\text { Cronbach's Alpha } \\
\text { Value }\end{array}$ \\
\hline Cognitive Identification & 9 & 0,899 & 0,000 & 0,862 \\
$\begin{array}{l}\text { Affective Identification } \\
\begin{array}{l}\text { All Scale Questions } \\
\text { (Perceived Organizational }\end{array}\end{array}$ & 9 & 0,919 & 0,000 & 0,904 \\
Identification) & 18 & 0,948 & 0,000 & 0,927 \\
\hline
\end{tabular}

The Cronbach's Alpha coefficient of the scale used to reveal the organizational identification perception of the employees who participated in this research was found to be 0.927 . When reliability results are evaluated together, it is seen that survey questions and research data are highly reliable.

Within the scope of the research, after determining the reliability of the organizational identification scale, it was examined whether the questions related to the scale have the suitability for factor analysis. Accordingly, the Barlett Sphericity Test was applied to determine whether there was a sufficient relationship between the variables and the $p$ value was calculated to be $0.000(p \leq 0.05)$, and this value was found to be significant (Table 2). Therefore, it was concluded that the variables were suitable for factor analysis. Kaiser Meyer-Olkin (KMO) test was used for inter-variable correlations and KMO value for organizational identification was calculated as 0.948. Accordingly, it was observed that the variables of the organizational identification scale were highly suitable for factor analysis. Table 3: Number of Factors Related to Eigenvalue Statistics and Percentage of Variance Explained

\begin{tabular}{|c|c|c|c|c|c|c|}
\hline \multirow[b]{2}{*}{ Component } & \multicolumn{3}{|c|}{ Initial Eigenvalues } & \multicolumn{3}{|c|}{ Rotation Sums of Squared Loadings } \\
\hline & Total & $\begin{array}{c}\% \text { of } \\
\text { Variance }\end{array}$ & $\begin{array}{c}\text { Cumulative } \\
\%\end{array}$ & Total & $\begin{array}{c}\% \text { of } \\
\text { Variance }\end{array}$ & $\begin{array}{l}\text { Cumulative } \\
\%\end{array}$ \\
\hline 1 & 8,517 & 47,318 & 47,318 & 5,198 & 28,877 & 28,877 \\
\hline 2 & 1,407 & 7,819 & 55,137 & 4,727 & 26,261 & 55,137 \\
\hline 3 & ,993 & 5,515 & 60,652 & & & \\
\hline 4 & ,788 & 4,378 & 65,030 & & & \\
\hline 5 & ,778 & 4,320 & 69,350 & & & \\
\hline 6 & 688 & 3,824 & 73,173 & & & \\
\hline 7 &, 560 & 3,109 & 76,283 & & & \\
\hline 8 & ,538 & 2,989 & 79,272 & & & \\
\hline 9 &, 510 & 2,834 & 82,105 & & & \\
\hline 10 & 457 & 2,537 & 84,642 & & & \\
\hline 11 & ,438 & 2,431 & 87,073 & & & \\
\hline 12 & ,393 & 2,184 & 89,257 & & & \\
\hline 13 & ,369 & 2,048 & 91,305 & & & \\
\hline 14 & ,348 & 1,932 & 93,237 & & & \\
\hline 15 & ,339 & 1,882 & 95,119 & & & \\
\hline 16 & ,313 & 1,737 & 96,856 & & & \\
\hline 17 & ,298 & 1,657 & 98,513 & & & \\
\hline 18 & 268 & 1,487 & 100,000 & & & \\
\hline
\end{tabular}

In addition, within the scope of factor analysis, the study was carried out to determine the percentage of the total variance of the factors of the organizational identification scale used in the research. In Table 3 , the factors of the organizational identification scale explain approximately $55.1 \%$ of the total variance. In the studies in the field of social sciences, it is accepted that the cumulative variance is between $40 \%$ and $60 \%$ (Tavsancil, 2002). Therefore, the percentage of variance described in the organizational identification scale was considered sufficient for this study. 
Table 4. Rotated Factor Matrix

\begin{tabular}{|c|c|c|}
\hline \multirow[b]{2}{*}{ Organizational Identification Components } & \multicolumn{2}{|c|}{ Component } \\
\hline & 1 & 2 \\
\hline 1. Prefer to be in an existing organization instead of other organizations to work & ,264 & ,658 \\
\hline 2. Be proud to work in the current organization & ,377 & ,700 \\
\hline 3 Thinking that workied organization has a distinctive difference compared to other organizations & ,296 &, 667 \\
\hline 4. Thinking that the current organization is more than a workplace for employees & ,059 &, 558 \\
\hline 5. Thinking that others see this organization as an example of excellence in business & ,256 & ,721 \\
\hline $\begin{array}{l}\text { 6. Compared with other organizations, he / she thinks that this organization is an example of } \\
\text { excellence in business life. }\end{array}$ & ,252 & ,738 \\
\hline 7. Thinking that there are many things that attract him / her to this organization & ,323 & ,667 \\
\hline 8. Be proud of the achievements of the organization & ,405 & ,615 \\
\hline 9. Use of the word "we" rather than "they" when talking about workied the organization & ,490 & ,491 \\
\hline 10. Be proud to tell people about this organization & ,586 &, 456 \\
\hline 11. Considering the success of the organization as his /her own success & ,691 & ,241 \\
\hline 12. Feeling like the owner of this organization & ,715 & ,243 \\
\hline $\begin{array}{l}\text { 13. When someone praises the current organization in which he / she is working, he / she perceives } \\
\text { it as a personal compliment. }\end{array}$ & ,780 &, 133 \\
\hline $\begin{array}{l}\text { 14. If the values of the organization which he / she is working are similar to their own values, the } \\
\text { situation of feeling themselves like belonging to this workplace }\end{array}$ & ,791 & , 195 \\
\hline $\begin{array}{l}\text { 15. When someone criticizes the current organization, he / she starts to defend the organization as if } \\
\text { it had criticized itself. }\end{array}$ & ,710 & ,290 \\
\hline $\begin{array}{l}\text { 16. When he / she started working in the current organization, his / her personal values were very } \\
\text { similar to the values of this organization. }\end{array}$ & ,659 &, 370 \\
\hline $\begin{array}{l}\text { 17. Its commitment to the present organization is based on the similarity of itself and the values of } \\
\text { the organization. }\end{array}$ & ,632 & ,390 \\
\hline $\begin{array}{l}\text { 18. The reason why he / she preferred this organization compared to other organizations is the belief } \\
\text { that the value judgments of this organization are established. }\end{array}$ & ,596 & ,405 \\
\hline
\end{tabular}

When the above Rotated Factor Matrix table values are analyzed, it is seen which expressions are collected under factor 1 and 2. In order to name the factors, variables with large weights were grouped under one factor. Accordingly, the variables that take the highest value under factor 1 are related to the affective aspect of organizational identification. The variables that take the highest value under factor 2 are related to the cognitive aspect of organizational identification. Therefore, the first factor can be named as "affective identification" in terms of organizational identification and the second factor as "cognitive identification". In this context, it was seen that the first 9 expressions in the organizational identification scale were related to cognitive identification and the last 9 expressions were related to affective identification. Therefore, firstly cognitive identification and then affective identification were included in the hypothesis of the study and testing of the hypotheses.

\subsection{Data Analysis and Research Findings}

In this part of the study, first of all; the descriptive statistics of the employees who participated in the survey were included. Then, the results of the Kruskal Wallis H and Spearman's rho correlation tests for testing the hypotheses identified within the scope of the research are discussed.

2.6.1 Descriptive Statistics

Different generations of employees; Descriptive characteristics such as age (generation status), gender, marital status, education level, work experience level, seniority in the institution, task status, income level, sector of employment are given in the tables below. 
Tablo 5: Descriptive Statistics of Independent Variables

\begin{tabular}{|c|c|c|c|c|c|c|c|}
\hline \multicolumn{2}{|c|}{ Independent Variable } & $\mathrm{N}$ & $\%$ & \multicolumn{2}{|c|}{ Independent Variable } & $\mathrm{N}$ & $\%$ \\
\hline \multirow{6}{*}{$\begin{array}{l}\text { Generation } \\
\text { Condition }\end{array}$} & Traditionalists & 9 & ,8 & \multirow{3}{*}{ Gender } & Female & 272 & 24,6 \\
\hline & Baby Boomers & 62 & 5,6 & & Male & 833 & 75,4 \\
\hline & Generation X & 314 & 28,4 & & Total & 1105 & 100,0 \\
\hline & Generation Y & 523 & 47,3 & \multirow{3}{*}{ Marital status } & Married & 644 & 58,3 \\
\hline & Generation Z & 197 & 17,9 & & Single & 461 & 41,7 \\
\hline & Total & 1105 & 100,0 & & Total & 1105 & 100,0 \\
\hline \multirow{7}{*}{$\begin{array}{l}\text { Education } \\
\text { level }\end{array}$} & Primary education & 398 & 36,0 & \multirow{7}{*}{$\begin{array}{c}\text { Work } \\
\text { Experience } \\
\text { Status }\end{array}$} & Less than 1 year & 126 & 11,4 \\
\hline & High school & 421 & 38,1 & & $1-5$ years & 365 & 33,1 \\
\hline & Associate Degree & 159 & 14,4 & & $6-10$ years & 311 & 28,1 \\
\hline & License & 107 & 9,7 & & $11-15$ years & 158 & 14,3 \\
\hline & Master's Degree & 16 & 1,4 & & $16-20$ years & 62 & 5,6 \\
\hline & Doctorate & 4 &, 4 & & 21 years and over & 83 & 7,5 \\
\hline & Total & 1105 & 100,0 & & Total & 1105 & 100,0 \\
\hline \multirow{6}{*}{$\begin{array}{l}\text { Seniority } \\
\text { Status }\end{array}$} & Less than 1 year & 210 & 19,0 & \multirow{7}{*}{ Task Status } & Worker & 735 & 66,6 \\
\hline & $1-3$ years & 359 & 32,5 & & Shift supervisor & 57 & 5,2 \\
\hline & 4-6 years & 273 & 24,7 & & Chef & 79 & 7,1 \\
\hline & $7-9$ years & 100 & 9,0 & & Craftsman & 138 & 12,5 \\
\hline & 10 years or more & 163 & 14,8 & & $\begin{array}{l}\text { Unit Manager / } \\
\text { Director Asst. }\end{array}$ & 58 & 5,2 \\
\hline & Total & 1105 & 100,0 & & Senior Executive & 38 & 3,4 \\
\hline \multirow{6}{*}{ Income Level } & Less than $2,000 \mathrm{TL}$ & 789 & 71,4 & & Total & 1105 & 100,0 \\
\hline & $\begin{array}{l}\text { Between } 2.000 \mathrm{TL} \\
\text { and } 2.999 \mathrm{TL}\end{array}$ & 250 & 22,6 & \multirow{5}{*}{$\begin{array}{c}\text { Sector of } \\
\text { Employment }\end{array}$} & Textile & 621 & 56,2 \\
\hline & 3000 TL and up & 66 & 6,0 & & Food & 234 & 21,2 \\
\hline & \multirow{3}{*}{ Total } & \multirow{3}{*}{1105} & \multirow{3}{*}{100,0} & & Plastic & 74 & 6,7 \\
\hline & & & & & Chemistry & 176 & 15,9 \\
\hline & & & & & Total & 1105 & 100,0 \\
\hline
\end{tabular}

The generational status of the employees who participated in the study were grouped in 5 groups. According to the generation status of the participants, $0.8 \%$ is Traditionalist, $5.6 \%$ is Baby Boomers, $28.4 \%$ is Generation $\mathrm{X}$, $47.3 \%$ is Generation $\mathrm{Y}$ and $17.9 \%$ is Generation $\mathrm{Z}$ employee. According to these results, as of 2017, it was observed that the majority of employees in the TRC1 Organized Industrial Zones consisted of Generation Y workers between the ages of 22-36, followed by Generation X workers aged 37-56. In addition, it is seen that the Baby Boomers generation and Traditionalists generation employees before the $\mathrm{X}$ generation correspond to only $6.4 \%$ of the total participants.

By Zemke et al. (2013), Will it work for the Traditionalists generation? Will he / she retire? Is he /she going to counsel? Seeking answers to questions; Postponing retirement for the Baby Boomers generation; The most powerful in the workplace for the $\mathrm{X}$ generation (survivalist); For the Millennium Generation, which includes the Generation $\mathrm{Y}$ and $\mathrm{Z}$, it is defined as the one that is careful about what it wants. However, since the fieldwork of this study was conducted in 2017 , it is clearly seen that the concept of survivalist in the workplaces shifts from generation $\mathrm{X}$ to generation $\mathrm{Y}$. The fact that the majority of the participants are $\mathrm{Y}$ and $\mathrm{X}$ employees can be considered as an important advantage especially for the differentiation of organizational identification perceptions.

When the gender distribution of the employees is examined, it is seen that approximately $25 \%$ of the participants are women and $75 \%$ are men. The fact that the majority of the employees within the scope of the research is male, draws attention to the density of male employees in enterprises operating in organized industrial zones. Accordingly, it can be said that most of the employees in the organized industrial zones in the TRC1 Region are men. According to TUIK 2017 data, the employment rate of those aged over 15 years in Turkey for men $65.1 \%$ and $28 \%$ for women. The results obtained in our study, the majority Turkey is close to the average (TUIK, "Women in Statistics 2017").

In addition, when the distribution of employees according to marital status is examined; $58.3 \%$ of the employees are married and $41.7 \%$ are single.

The level of education of the employees in the research is divided into groups. When the distribution of the participants according to education groups is examined, $38.1 \%$ have high school, $36 \%$ have primary education, $14.4 \%$ have associate degree and $11.5 \%$ have undergraduate and graduate education level. Accordingly, it can be said that the majority of the employees participating in the study are primary and high school graduates, and they 
work in a job where the necessary competencies or job requirements are not very high. In addition, the fact that the undergraduate and graduate education level among the participants is quite low compared to the other participants shows that the higher education level of the employee is not sought within the job requirements.

The level of work experience of the employees in the research was divided into groups. It is seen that $33 \%$ of the participants have $1-5$ years of experience, $28.1 \%$ of them have $6-10$ years of experience and $27.4 \%$ of them have 11 years and more work experience. In terms of work experience duration, it is seen that the employees with 15 years and more work experience are at a very low rate among the total participants and that the employees in TRC1 Organized Industrial Zones do not continue their work for many years. It is seen that the largest majority (61.1\%) consists of employees with 1-10 years of work experience.

When the seniority status of the participants were examined; It was determined that $32.5 \%$ had seniority between 1-3 years, $24.7 \%$ between $4-6$ years, $19 \%$ had less than 1 year and $14.8 \%$ had seniority of 10 years or more. It is seen that the majority of the participants $(76.2 \%)$ are 6 years and below the seniority status in the enterprises. When the job experience levels of the participants and seniority status in the enterprise are evaluated together, it can be said that the labor turnover rate in enterprises in this region is high.

In terms of the job status of the employees participating in the research; $66.6 \%$ were workers, $24.8 \%$ were senior managers (craftsman, chief and shift supervisor), 5.2\% were middle managers (unit managers and assistants) and $3.4 \%$ were senior level managers. In testing the hypotheses of the study; The employees who participated in the study were examined as workers, subordinate managers (shift supervisor, chief and master), middle managers (unit managers and assistant managers) and senior managers.

When the incomes of the participants are examined; it is seen that $71.4 \%$ of the employees who participated in the survey had less than 2.000.-TL, $22.6 \%$ of the employees had between 2.000.-TL- 2.999.-TL and $6 \%$ of the employees had the income of 3.000.-TL and above. According to these results, it was observed that the majority of the participants had income below 2,000.- TL. When the task status and income levels of the participants were evaluated together, it was seen that 96 participants worked at the top and middle management levels (senior managers, unit managers and assistant managers) and 66 participants received 3,000.-TL or more income. Accordingly, it can be concluded that the difference in income level of the participants stems from their task status.

When the sectors in which the participants work are examined; It is seen that $56.2 \%$ of the employees participating in the research work in textile sector, $21.2 \%$ work in food sector, $6.7 \%$ work in plastic sector and $15.9 \%$ work in chemical sector. In this study, it was seen that the majority of the participants worked in the textile sector.

2.6.2. Kruskal Wallis H Test and Correlation Test Used in the Analysis of Hypotheses

The results of the Spearman's rho correlation test used to examine the relationship between the dimensions of perceived organizational identification and the Kruskal Wallis $\mathrm{H}$ test used to test the hypotheses developed to detect the perceived organizational identification level differences of the different generation employees participating in the study are given below in terms of the main and sub-hypotheses.

a) Analysis of Differences in Organizational Identification of Employees of Different Generations

The Kruskal Wallis H test was used to determine whether there is a significant difference between the perception of organizational identification and the status of the different generation employees.

1. $\mathrm{H}_{0}$ : There are no significant differences between the levels of organizational identification perceived by different generation employees.

1. $\mathrm{H}_{1}$ : There are significant differences between the levels of organizational identification perceived by different generation employees.

Table 6. The Results of the Analysis of the Differences in Perception of Organizational Identification of Different Generation Employees

\begin{tabular}{|c|c|c|c|c|c|}
\hline Generation Condition & $\mathrm{N}$ & Mean Rank & Chi-Square & df & $\mathrm{p}$ \\
\hline Traditionalists & 9 & 614,11 & & & \\
\hline Baby Boomers & 62 & 549,60 & 26,886 & 4 &, 000 \\
\hline Generation X & 314 & 624,95 & & & \\
\hline Generation Y & 523 & 534,58 & & & \\
\hline Generation Z & 197 & 485,51 & & & \\
\hline Total & 1105 & & & & \\
\hline
\end{tabular}

As can be seen in Table 6, there are significant differences between the levels of organizational identification perceived by the different generation employees $(\mathrm{p}=0.000<0.05)$. According to mean rank; The highest organizational identification perception was determined by the employee of Generation $\mathrm{X}$ and the lowest organizational identification perception by the employee of Generation Z. In this context, the first hypothesis, 1. $\mathrm{H}_{0}$ : "There are no significant differences between the levels of organizational identification perceived by different generation employees", which is the main hypothesis of the study, was rejected; in contrast, the alternative hypothesis, $\mathrm{H}_{1}$ : "There are significant differences between the levels of organizational identification perceived by different generation employees", has been accepted. 
In addition, organizational identification levels of different generation employees were analyzed with Kruskal Wallis $\mathrm{H}$ test in terms of sub-dimensions.

Table 7. Kruskal Wallis H Test Results of the Levels of Perceptions of Different Generation Employees Towards "Cognitive" and "Affective" Dimensions of Organizational Identification

\begin{tabular}{|c|c|c|c|c|c|c|}
\hline $\begin{array}{l}\text { Dimensions of } \\
\text { Organizational } \\
\text { Identification }\end{array}$ & $\begin{array}{l}\text { Generation } \\
\text { Condition }\end{array}$ & $\mathrm{N}$ & Mean Rank & Chi-Square & df & $\begin{array}{l}\text { Asymp. } \\
\text { Sig. }\end{array}$ \\
\hline \multirow{6}{*}{ Cognitive } & Traditionalists & 9 & 601,83 & \multirow{6}{*}{21,137} & \multirow{6}{*}{4} & \multirow{6}{*}{,000 } \\
\hline & Baby Boomers & 62 & 536,08 & & & \\
\hline & Generation X & 314 & 620,49 & & & \\
\hline & Generation Y & 523 & 531,18 & & & \\
\hline & Generation $\mathrm{Z}$ & 197 & 506,46 & & & \\
\hline & Total & 1105 & & & & \\
\hline \multirow{6}{*}{ Affective } & Traditionalists & 9 & 617,44 & \multirow{6}{*}{25,670} & \multirow{6}{*}{4} & \multirow{6}{*}{, 000} \\
\hline & Baby Boomers & 62 & 559,07 & & & \\
\hline & Generation X & 314 & 618,87 & & & \\
\hline & Generation Y & 523 & 539,87 & & & \\
\hline & Generation $\mathrm{Z}$ & 197 & 478,02 & & & \\
\hline & Total & 1105 & & & & \\
\hline
\end{tabular}

According to Table 7, significant differences were found between the perception levels of cognitive and affective dimensions of organizational identification of different generation employees $(p=0.000<0.05)$. In this context; $\mathrm{H}_{0} .1 .1$ and $\mathrm{H}_{0} .1 .2$ hypotheses were rejected, but on the contrary; $\mathrm{H}_{1} .1 .1$ and $\mathrm{H}_{1} .1 .2$ hypotheses were accepted. When the mean ranks values are analyzed, it is seen that the perception levels of the cognitive and affective dimensions of organizational identification of employees of different generations tend to decrease especially after generation X. In other words, it is revealed that generation X employee has a higher level of organizational identification perception than both employee $\mathrm{Y}$ and $\mathrm{Z}$ generation employees, and generation $\mathrm{Y}$ has a higher level of organizational identification perception than employee $Z$ generation. When all generation employees are evaluated together, both the cognitive, affective and general organizational identification levels of the $\mathrm{X}$ generation; the lowest level of organizational identification was found to be $\mathrm{Z}$ generation. Moreover, these three generations constitute the most important employees in today's business life.

b) Correlation Analysis

Spearman's rho test was used to determine whether there is a relationship between the cognitive and affective dimensions of organizational identification of employees.

2. $\mathrm{H}_{0}$ : There was no significant relationship between cognitive and affective dimensions of perceived organizational identification.

$\mathrm{H}_{1}$ : There was significant relationship between cognitive and affective dimensions of perceived organizational identification.

Table 8. Analysis of the Relationship Between Perception Levels of Cognitive and Affective Dimensions of Organizational Identification with Spearman's rho Test

\begin{tabular}{|l|c|c|}
\hline Dimensions of Organizational Identification & Cognitive & Affective \\
\hline Cognitive & 1,000 & $\mathbf{7 4 5}^{\text {** }}$ \\
\hline Affective & $\mathbf{, 7 4 5}^{\text {*** }}$ & 1,000 \\
\hline
\end{tabular}

**. Correlation is significant at the 0.01 level (2-tailed).

As can be seen in Table 8, there is a high level of positive correlation between employees' perception levels of cognitive and affective dimensions of organizational identification. In this context; $2 . \mathrm{H}_{0}$ : "There is no significant relationship between cognitive and affective dimensions of perceived organizational identification" hypothesis is rejected; on the contrary; $2 . \mathrm{H}_{1}$ : "There is a significant relationship between cognitive and affective dimensions of perceived organizational identification" hypothesis is accepted.

\section{Conclusions and Recommendations}

In this study, organizational identification level differences of different generation employees in enterprises operating in TRC1 (Gaziantep, Adiyaman, Kilis) Organized Industrial zones were examined. In this context, in the first part of the study, the information about generation concept and characteristic features, organizational identification and its components which are examined with theoretical and empirical features are formed. Thus, the integrity between the theoretical base and the content of the research was achieved. The research focuses on the Traditionalists, Baby Boomers, Generation X, Generation Y and Generation Z. However, the employees of X, $\mathrm{Y}$ and $\mathrm{Z}$ generations within the last three generations, which are mostly together in today's business life, have occupied a large part in the data set of this research. As the main population of this study, different generation 
employees in the enterprises operating in TRC1 Region (Gaziantep, Adiyaman, Kilis) Organized Industrial Zones were discussed. The main population of the study consists of 131,669 people in TRC1 Organized Industrial Zone. The questionnaire forms were applied to 1,105 employees selected by simple random sampling method in enterprises operating in organized industrial zones in Gaziantep, Adıyaman and Kilis provinces. Accordingly, $0.8 \%$ of the main population of TRC1 Organized Industrial Zone has been reached.

Considering the constraints on data collection that are effective in such researches, questions were asked about the issues that employees of the Traditionalists, Baby Boomers, Generation X, Generation Y and Generation $\mathrm{Z}$ can answer in a valid and reliable manner. It was accepted that the participants understood the questionnaire questions correctly and in the same way and gave answers and information reflecting the real situation.

Regarding the first main hypothesis of the study; Kruskal Wallis $\mathrm{H}$ test was used to analyze whether or not there was a significant difference between the levels of organizational identification perceived by the different generation of employees. As a result of the analysis, it was found that employees' being from Traditionalists, Baby Boomers, Generation X, Generation Y and Generation $Z$ were reflected to organizational identification perception levels in different ways $(\mathrm{p}=0.00<0.05)$. In this context; the first main hypothesis of the study was rejected $1 . \mathrm{H}_{0}$; on the contrary; $1 . \mathrm{H}_{1}$ is accepted. When the mean rank values were examined, it was determined that the highest perception was obtained by the $\mathrm{X}$ generation employee and the lowest perception by the $\mathrm{Z}$ generation employee in terms of organizational identification perception differences according to generational status of employees. However, as of 2019, the Traditionalists, the youngest at 74, and the Baby Boomers Generation, the youngest at 59 , are either not alive or retired or are in retirement. Therefore, it would be more appropriate to evaluate the last three generations (X, Y and $\mathrm{Z}$ ) actively involved in business life. Accordingly, in terms of the last three generations ( $\mathrm{X}, \mathrm{Y}$ and $\mathrm{Z}$ generation) employee, when the ordered average values are examined, it is observed that generation $\mathrm{X}$ employee has a higher level of identification perception than both $\mathrm{Y}$ and $\mathrm{Z}$ generation employees. In addition, generation $\mathrm{Y}$ has a higher level of identification perception than employee $\mathrm{Z}$ generation. According to these findings, it can be said that the perception of organizational identification of younger generations decreased. In particular, the reasons for the low level of organizational identification perception of generation $\mathrm{Z}$ which will take an active role in the future business world can be investigated. In order to increase the level of perception of organizational identification, which may have direct and / or indirect effects, especially in young generations, it is necessary to realize the necessary managerial plans, programs, actions and discourses in achieving the positive results.

In addition, in relation to the sub-hypotheses of the first main hypothesis of the study; significant differences were found between the perception levels of cognitive and affective dimensions of organizational identification of employees of different generations $(p=0.00<0.05)$. In this context; the hypotheses $\mathrm{H}_{0} .1 .1$ and $\mathrm{H}_{0} .1 .2$, the subhypotheses of the study, were rejected; on the contrary; The hypotheses $\mathrm{H}_{1} .1 .1$ and $\mathrm{H}_{1} .1 .2$ were accepted. Regarding both cognitive and affective identification, which are sub-dimensions of organizational identification, generation $\mathrm{X}$ employee had higher cognitive and affective identification perception than employee $\mathrm{Y}$ and $\mathrm{Z}$ generation. Generation $Y$ had a higher level of cognitive and affective identification perception than employee $Z$. Generation $\mathrm{Y}$ employee started to work after generation $\mathrm{X}$ employee. Generation $\mathrm{Z}$ employee started to work after generation $\mathrm{Y}$ and $\mathrm{X}$. So the youngest employee is the $\mathrm{Z}$ generation employee. Accordingly, when the first main hypothesis and sub-hypotheses of the study are evaluated together, it can be said that the organizational identification levels of the younger generation employees are significantly lower than those of the previous generation employees. In this study, it was found that the organizational identification levels decreased as the generation status of the employees was younger, and Aka (2017) showed that organizational commitment levels decreased as the younger generations became younger. Therefore, the findings of this study support the findings of Aka (2017).

As a result of the analysis of the second main hypothesis of the study with Spearman testis rho correlation test, a significant and positive relationship was found between the "cognitive" and "affective" dimensions of perceived organizational identification $(\mathrm{r}=0,745)$. In this context, the second main hypothesis of the study, hypothesis $2 . \mathrm{H}_{1}$ was accepted. Accordingly, when cognitive identification perception levels increase, affective identification perception levels increase as well; When perception levels towards cognitive identification decrease, affective identification perception levels also decrease. On the contrary, when the perception levels of emotional identification increase, cognitive identification perception levels increase as well; When perception levels towards affective identification decreased, cognitive identification perception levels also decreased.

As a result, it can be said that increasing the organizational identification perception levels of employees of different generations will increase employee loyalty, decrease their absenteeism, will make more efforts to reach the goals and objectives of the organization and consequently positive developments will emerge in the success indicators of the organization.

The results of this study may not be generalized for all times for employees in Turkey and those in organized industrial zones or other different regions. Because the generational division of employees may vary regionally. This is a limited study, but the findings of the perception of organizational identification of employees of different generations have provided guidance to researchers and managers. On the other hand, whether the findings are valid 
in other regions should be determined by other studies. For this reason, it is recommended that similar studies be conducted in different organized industrial zones.

\section{References}

Adiguzel, O., Batur, H.Z. et al., (2014). "New Work Thesis Emerging with the Changing Face of Generations and Generation Y: Mobile Collar”, Journal of Institute of Social Sciences, Süleyman Demirel University, 2014/1, (19), pp.165-182.

Aka, B. (2017). Public and Generation Differences in Employee Manager of the Private Sector And The Relationship Between Organizational Commitment Level: In Izmir Province Research, (Unpublished PhD Thesis), Izmir Clerk Celebi University Institute of Social Sciences, Izmir (Turkey).

Balci A., Baltaci A., T., Cereci, C., Acar U. (2012). "The Relationship of Organizational Socialization with Organizational Identification and Organizational Citizenship: A Research on Primary School Administrators", Journal of Educational Sciences Research, 2 (2), pp. 47-74.

Cheney, G., Tompkins, P. K. (1982). "Coming to Terms with Organizational Identification and Commitment", Central States Speech Journal, 38(1).

Cakinberk, A., Derin, N. and Demirel, E. T., (2011). Formation of Public Identification with Public Commitment: The Case of Malatya and Tunceli Private Educational Institutions", Journal of Business Research, 3, (1), pp. 89-121.

Cirakoglu, H., (2010). “Organizational Identification and Job Satisfaction Relations”, Institute of Social Sciences (Unpublished Master Thesis), Dokuz Eylul University, Izmir (Turkey).

Dereli, B. and Toruntay, H. (2011), "Management of Generations in Organizations Based on Business Values, Motivation and Mentoring Concepts", Istanbul Commerce University Foreign Trade Institute Discussion Papers, WPS No:03/2015-05. <http://www.ticaret.edu.tr/uploads/dosyalar/921/orgut.pdf> (12.16.2017).

Dutton, J.E., Dukerich, J. M. and Harquail, C.V., "Organizational Images and Member Identification", Administrative Science Quarterly, 1994, 39(2), pp. 239-263.

Erden, S. (2012). "Investigation of the Effects of Cultural Changes on Intergenerational Conflicts in Organizations: A Research for Academicians". (Unpublished PhD Thesis), Çanakkale 18 Mart University, Institute of Social Sciences, Çanakkale (Turkey).

Ertas, G. D. (2017). "X, Y Generation Differences in Organizational Businesses and Their Effect on Organizational Commitment”, (Unpublished Master Thesis). Eskişehir Anadolu University. Eskişehir (Turkey).

Iscan, F. O., (2006). "The Role of Individual Differences in the Relationship between Transformative / Interactiveist Leadership Perception and Organizational Identification", Journal of Economics and Administrative Sciences of Akdeniz University, 6 (11), pp. 160-177.

Karaaslan, S. (2014), "Understanding Intergenerational Differences Through Organizations: A Field Study", (Unpublished Master Thesis), Ankara University, Institute of Social Sciences, Ankara (Turkey).

Karabey, C. N. and Iscan, O. F. (2007). "Relationship between Organizational Identification, Organizational Image and Organizational Citizenship Behavior: An Application”, Atatürk University Journal of Economics and Administrative Sciences, 21(2), pp. 231-241.

Mael, F. and Ashforth, Blake, E. (1992). "Alumni and Their Alma Mater: A Partial Test of The Reformulated Model of Organizational Identification”, Journal of Organizatinal Behaviour, 13(2), pp.103-123.

Polat, M. and Meydan, C. H. (2010). A Research on the Relationship between Organizational Identification and Cynicism and Intention to Leave. Turkish Journal of Defense Sciences Institute, pp. 145-172.

Pratt, M. G. (1998). "To Be Or Not To Be? Central Questions in Organizational Identification" Identity in Organizations: Developing Theory Truogh Conversations, (Ed. D. Whtten and P. Godfrey), Thousand Oaks, USA.

Saruhan, S., (2017). "The Effect of Organizational Socialization on Organizational Identification”. (Unpublished Master Thesis) Kirıkkale University, Institute of Social Sciences, Kırıkkale (Turkey).

Schuman, H. and Scott, J. (1989). "Generations and Collective Memories", American Sociological Review, 54(3), pp. 359-381.

Stern, P. J. (2002). "Generational differences", The Journal of Hand Surgery, 27(2), pp. 187-194. http://www.jhandsurg.org/article/S0363-5023(02)50500-1/pdf (15.07.2015).

Tavsancil, E., (2002), Measurement of Attitudes and Data Analysis with SPSS, Nobel Publications, Ankara.

Tuik. (2017). Woman with statistics. Turkish Statistical Institute Newsletter, Ankara.

Usta, O. (2014), A Research to Analyze the Impact of Generation Difference on Business Values, (Unpublished Master Thesis), Dokuz Eylül University, Institute of Social Sciences, İzmir (Turkey).

Zemke, R., Raines, C. and Filipczak, B. (2013), Generations at Work: Managing the Clash of Boomers, Gen Xers, and Gen Yers in the Workplace, (2nd Edition), Amacom Press, USA.

Linked Resources:

$<$ http://www.adiyaman.gov.tr/ekonomik-durumu $>$ (28.10.2017). 
$<$ http://www.kilisosb.org.tr/bilgi.asp?aid=2> (13.07.2015).

$<$ https://www.gaosb.org.tr $>(01.01 .2015)$.

$<$ www.ika.org.tr $>(13.07 .2015)$.

$<$ www.tdk.gov.tr $>(25.11 .2018)$.

G. Kirpik is an academician at Pharmacy Management in Pharmacy Faculty of Adiyaman University in Turkey. In 1999, he graduated from Çukurova University, Faculty of Economics and Administrative Sciences, Department of Business Administration (English). In 2002, she completed her master's degree at Çukurova University, Institute of Social Sciences, Department of Business Administration. In 2018, she received her doctorate degree from İnönü University, Institute of Social Sciences, Department of Business Administration and Organization. She teachs business administration related to pharmacy. She has many papers, articles and books on business and management-organization issues (corporate reputation management, organizational identification, business performance, organizational commitment, intergenerational differences, etc.).

Bunyamin Akdemir is an academician in the Department of Business Administration, Faculty of Economics and Administrative Sciences at Inonu University. In 1995, he graduated from Inonu University, Faculty of Economics and Administrative Sciences, Department of Business Administration. In 1999, he completed his master's degree at Inonu University, Institute of Social Sciences, Department of Business Administration. In 2004, he completed his doctorate in Istanbul University, Institute of Social Sciences, Department of Business Administration and Management. Since 2017, he has been working as a professor at Inonu University, Faculty of Economics and Administrative Sciences, Department of Business Administration. He has published extensively on national and international level in the fields of management and organization, human resources management, management and strategy, organizational behavior and management psychology. 